\title{
STUDI KINETIKA EKSTRAK DAN GETAH TUMBUHAN PATAH TULANG (EUPHORBIA TIRUCALLI) TERHADAP PENYEMBUHAN PADA KULIT
}

\author{
Mutiara Sukma*1 \\ ${ }^{1}$ Pendidikan Kimia,FMIPA, Universitas Negeri Padang, Indonesia \\ *Email : Mutiara337@gmail.com
}

\begin{abstract}
Abstrak. Studi ini bertujuan untuk membuat ekstrak dari tumbuhan patah tulang (Euphorbia tirucalli) terhadap penyembuhan pada kulit . Metode yang dilakukan adalah eksperimen dan uji aktivitas katalitik secara langsung. Tahapan pertama dilakukan dengan pembuatan ekstrak dari tumbuhan patah tulang (Euphorbia tirucalli) . Uji aktivitas langsung dilakukan dengan variasi berupa tetesantetesan selama 2-3 hari. Hasil eksperimen membuktikan bahwa ekstrak dari tumbuhan patah tulang (Euphorbia tirucalli) dapat menghilangkan tahi lalat yang membesar, menghilangkan kulit yang menebal atau kutil, mengeluarkan duri yang tertusuk pada kulit, serta meredakan patah tulang. Kondisi optimum ekstrak dari tumbuhan patah tulang tergantung kepada keluhan yang dialami. Penyembuhan ini diduga karena aktivitas katalitik ekstrak dari tumbuhan patah tulang (Euphorbia tirucalli) terhadap getah dan ranting atau dahannya.
\end{abstract}

Keywords : katalitik, ekstrak tumbuhan patah tulang (Euphorbia tirucalli), penyembuhan pada kulit .

\section{A. PENDAhULUAN}

Reaksi [1] kimia [2] merupakan suatu perubahan [3] yang menghasilkan senyawa [4] baru. Dalam reaksi [5] kimia [6] yang terlibat didalam reaksi [7] tersebut adalah reaktan [8]. Perubahan [9] yang terjadi dalam reaksi [10] kimia [11] yaitu perubahan [12] secara kimiawi [13] yang menghasilkan satu atau lebih senyawa [14] baru yang biasa disebut sebagai produk [15]. Perubahan-perubahan 
[16] yang biasanya terjadi dalam reaksi [17] kimia [18] yaitu perubahan [19] warna [20], timbulnya gas [21], adanya endapan [22], dan perubahan suhu [23]. Biasanya dalam reaksi [] kimia [] adanya suatu katalis [], dimana katalis [] digunakan untuk mempercepat terjadinya suatu reaksi [24] kimia [25].

Katalis [26] atau katalitik [27] merupakan zat [28] yang dapat mempercepat [29] terjadi nya suatu reaksi [30] kimia [31] yang berperan dalam suatu reaksi [32]. Katalis [] dibedakan menjadi katalis [33] heterogen [34] dan katalis [35] homogen [36], katalis heterogen [37] merupakan katalis yang memiliki fasa [38] yang berbeda dengan pereaksinya [39] dalam reaksi kimia [40] dan katalis homogen [41] merupakan katalis [42] yang memiliki fasa [43] yang sama dengan pereaksinya [44] dalam suatu reaksi kimia [45].

Tumbuhan [46] patah tulang [47] memiliki nama latin Euphorbia tirucalli [48] berasal dari Afrika tropis [49]. Tumbuhan [50] ini termasuk dalam genus Euphorbia [51], spesies E.tirucalli [52], dan famili Euphorbiaceae [53]. Tumbuhan [54] patah tulang (Euphorbia tirucalli) [55] di Sunda [56] dikenal dengan susuran, [57] di Jawa dikenal dengan kayu arip [58], pacing tawa [59], tikel balung sedang [60] di Madura dikenal sebagai kayu langtolangan,kayu jaliso [61], kayu leso [62], kayu tabar [63].

Tumbuhan [64] patah tulang (Euphorbia tirucalli) [65] ini dapat ditemukan didataran rendah [66]. Tumbuhan patah tulang (Euphorbia tirucalli) [67] memiliki pangkal [68] yang berkayu [69] dan cabang [70] yang banyak dan juga memiliki getah seperti susu. [71] Tumbuhan ini memiliki ranting [72] yang menyerupai pensil [73] yang berwarna hijau [74]. Daunnya [75] terdapat pada ujung ranting 
[76] yang berukuran kecil [77]. Bunga [78] pada tumbuhan [79] patah tulang (Euphorbia tirucalli) [80] ini biasanya tersusun dalam mangkuk [81] dan akan keluar pada ujung rantingnya. [82] Tumbuhan [83] patah tulang (Euphorbia tirucalli) tidak memiliki daun [84] dan hanya tersusun atas batang [85] yang menyerupai tulang belulang [86] yang merupakan ciri khas pada tumbuhan ini [87]. [88] Dan getah yang terkandung pada tumbuhan ini secara empiris [89] terbukti dapat mengobati luka [90].

Tumbuhan patah tulang (Euphorbia tirucalli) [91] yang paling sering dimanfaatkan untuk obat [92] yaitu bagian kulit batang [93], ranting [94], maupun getahnya [95]. [96] Dimana penggunaan tumbuhan ini dapat mencegah beberapa penyakit [97] pada kulit diantaranya mencegah tahi lalat membesar [98], kapalan [99] dan kutil [100], kulit tertusuk dari duri [101] atau terkena pecahan kaca [102] bahkan juga dapat menyembuhkan [103] sakit gigi [104]. Tumbuhan [105] patah tulang (Euphorbia tirucalli) [106] mengandung glikosid [107], sapogenin [108], terpenoid [109], alkaloid [110], tannin [111]. Pada getah tanaman [112] patah tulang (Euphorbia tirucalli) [113] ini mengandung senyawa [114] euforbon [115118], taraksasterol [119-121], $\alpha$ - Laktuserol [122-125], eufol [126-130] dan senyawa [131] damar [132-135]. Tujuan dari penelitian ini yaitu untuk mengetahui apakah ekstrak [136-146] dari tumbuhan [147] patah tulang (Euphorbia tirucalli) [148] mampu menyembuhkan luka [149] atau kelainan pada kulit [150].

\section{B. METODE}

\section{Alat dan Bahan}

Peralatan yang digunakan untuk membuat ekstrak dari tumbuhan patah tulang ini sebagai berikut : 

a. Wadah (Tuppeware)
b. Penyaring Plastik (Nagata)
c. Alat Untuk Merebus (Steele)
d. Blender (Philips)
e. Pisau (Joyko)
f. Cotton bods

Bahan yang digunakan untuk membuat ekstrak dari tumbuhan patah tulang ini sebagai berikut :
a. Dahan dari tumbuhan patah tulang.
b. Ranting dari tumbuhan patah tulang.
c. Getah yang didapat dari tumbuhan patah tulang.
d. Perasan dari air jeruk.
e. Air (Aqua).

\section{Prosedur Kerja}

a. Penyiapan Sampel

Sampel yang digunakan diambil dari salah satu tanaman warga di Jalan Gajah IV No.12 Air Tawar Barat, Padang Utara. Sampel yang diambil sebanyak $1 \mathrm{~kg}$. Sampel yang diambil terlebih dahulu dicuci. 

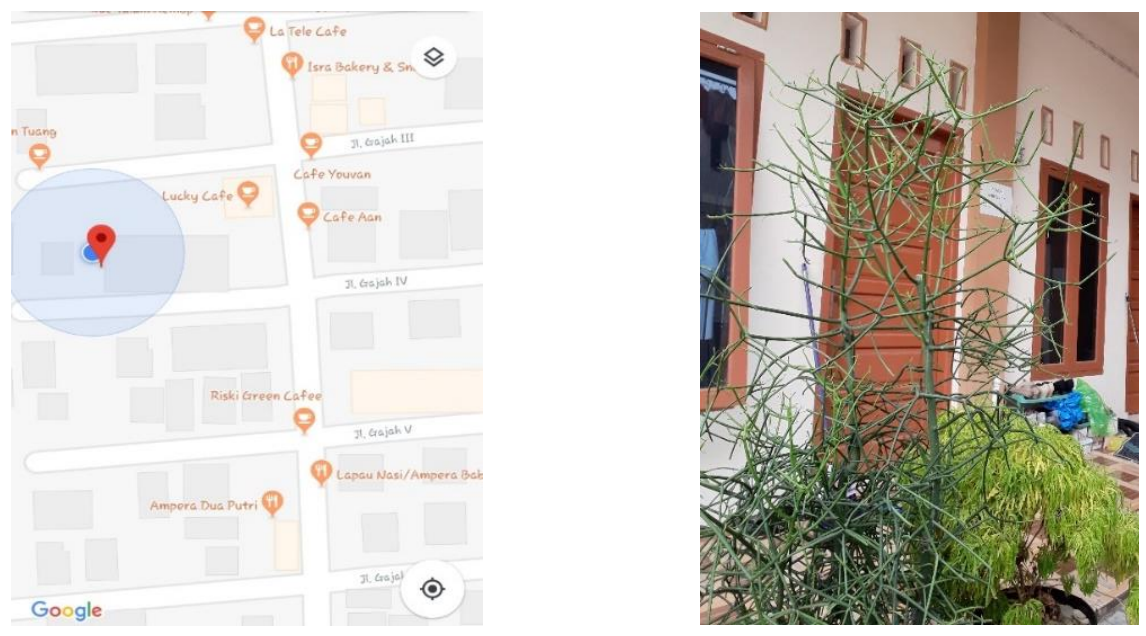

Gambar 1. Lokasi pengambilan sampel. Gambar 2. Tumbuhan Patah Tulang (sukma, 2019)
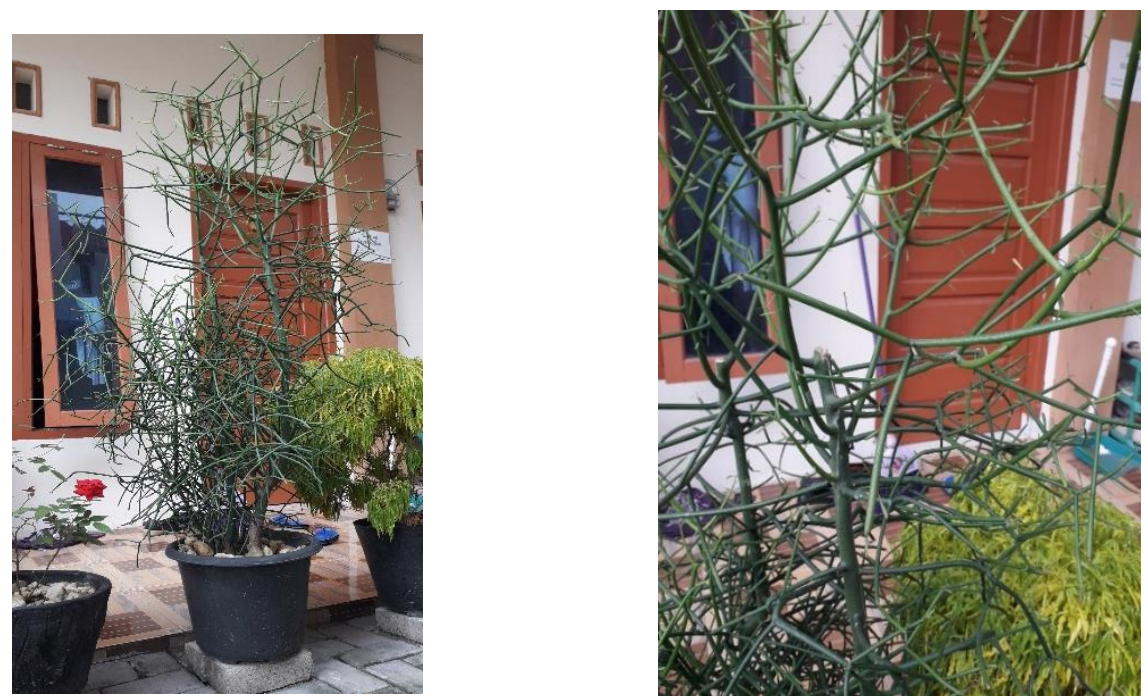

Gambar 3. Tumbuhan Patah Tulang Gambar 4. Ranting dan Dahan sampel (sukma, 2019)

\section{b. Pembuatan Sampel}

Pada tumbuhan patah tulang (Euphorbia tirucalli) ini ekstrak yang dihasilkan berupa getah, dimana cara memperoleh ekstrak atau getah tersebut dengan memotong-motong dahan sehingga diperoleh tetesantetesan dari getah pada dahan tersebut. Tergantung kepada penanganan yang dilakukan, untuk meredakan sakit pada patah tulang, beberapa dahan dan ranting digiling halus. 


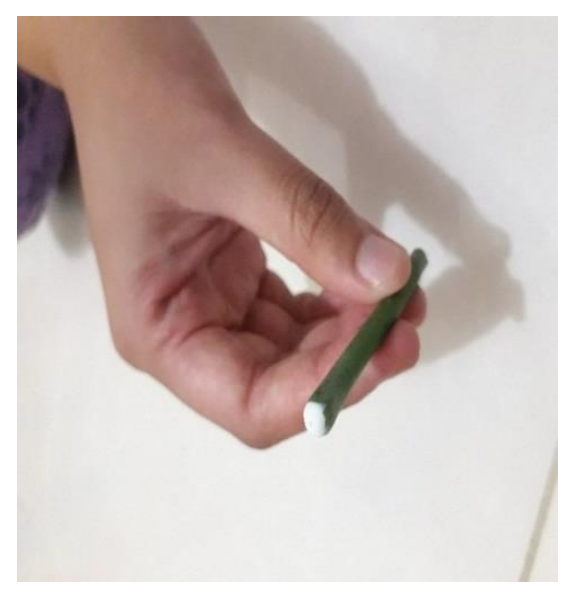

Gambar 5. Getah yang diperoleh (sukma, 2019)

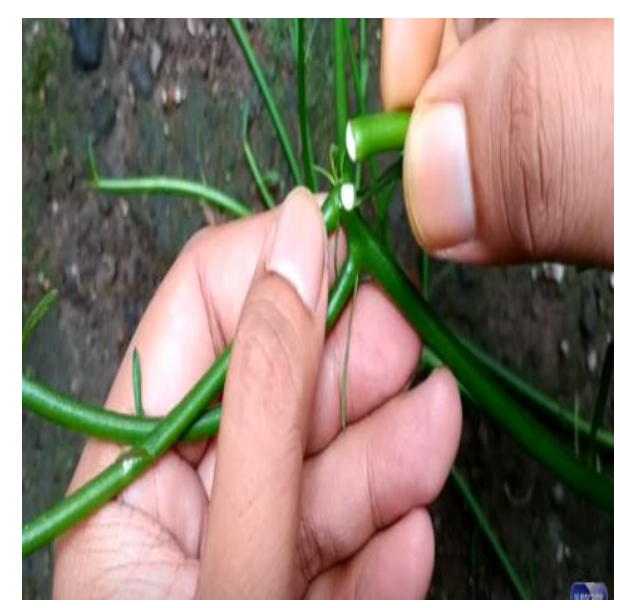

Gambar 6.

(https://www.youtube.com/watch?v=lyGoVTrtVIU)

c. Pengujian ekstrak

Ekstrak yang sudah ada dilakukan pengujian terhadap :

\begin{tabular}{|c|c|}
\hline Pengujian & Hasil dari pengujian \\
\hline $\begin{array}{l}\text { Untuk menghilangkan } \\
\text { tahi lalat yang } \\
\text { membesar } \\
\text { Terlebih dahulu } \\
\text { bersihkan tahi lalat } \\
\text { dengan air jeruk nipis } \\
\text { Olesi tahi lalat } \\
\text { dengan getah } \\
\text { patah tulang }\end{array}$ & $\begin{array}{l}\text { Dari hasil pengujian didapatkan hasil } \\
\text { sebagaimana pemberian getah } \\
\text { dilakukan } 2 \text { hari dengan pemberian } \\
\text { dilakukan } 2 \text { kali sehari pagi dan sore. }\end{array}$ \\
\hline
\end{tabular}




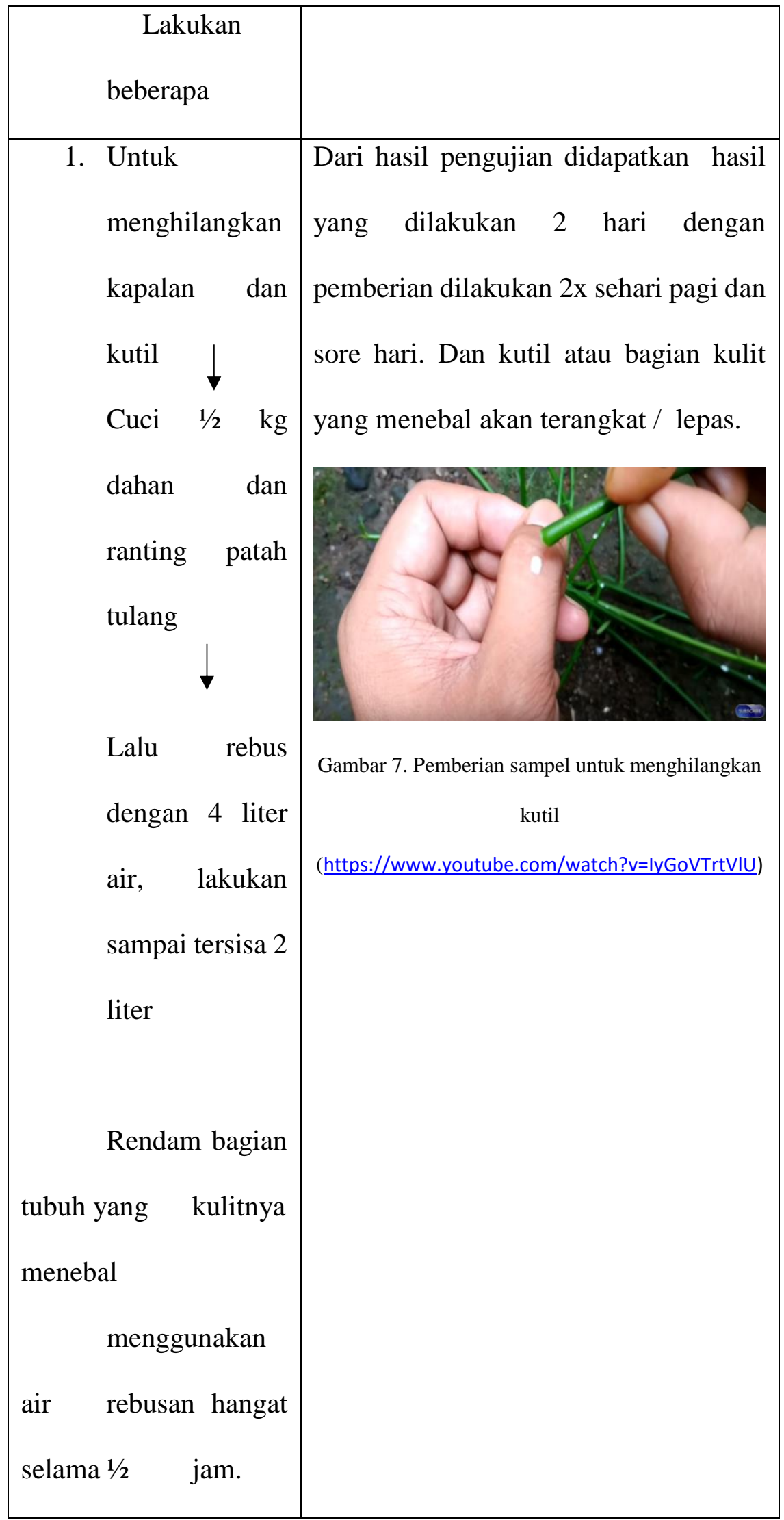




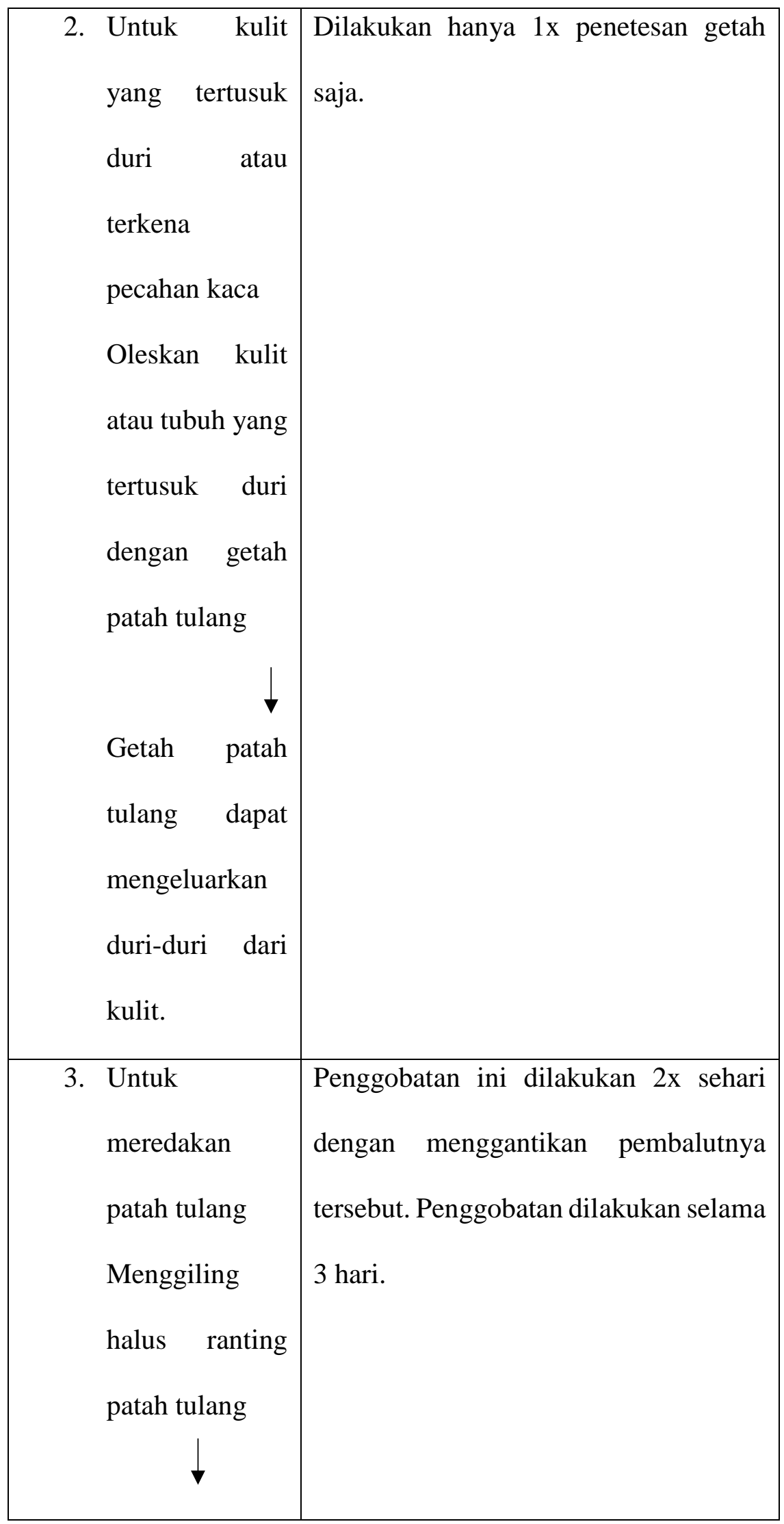




\begin{tabular}{|l|l|}
\hline Menepelkan & \\
hasil & gilingan \\
diatas & tulang \\
yang patah & \\
kemudian balut & \\
\hline
\end{tabular}

\section{HASIL}

1. Hasil Pembuatan

Hasil ekstrak atau getah yang diperoleh dari 1kilogram ranting atau dahan tumbuhan patah tulang sebanyak $5 \mathrm{ml}$. Hal ini dapat dilihat pada gambar berikut :
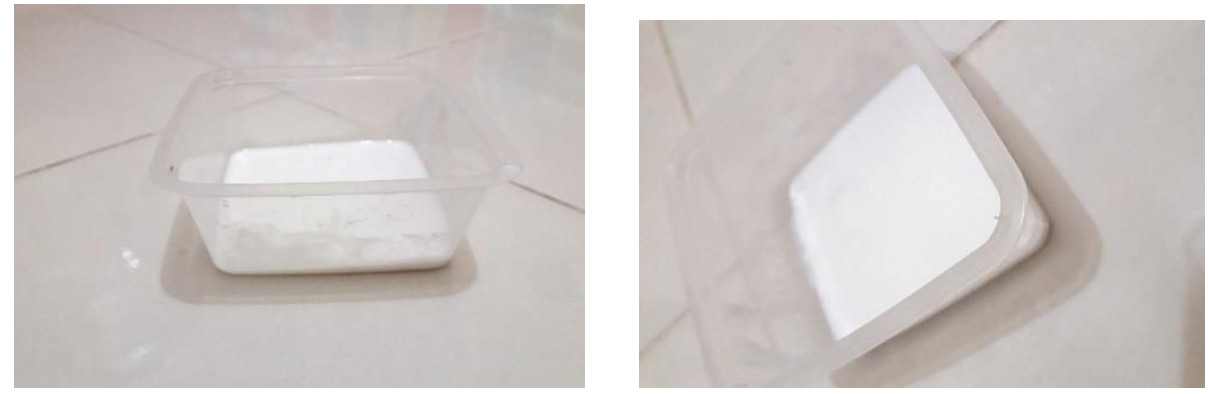

Gambar 8. Hasil ekstrak atau getah yang diperoleh (sukma, 2019)
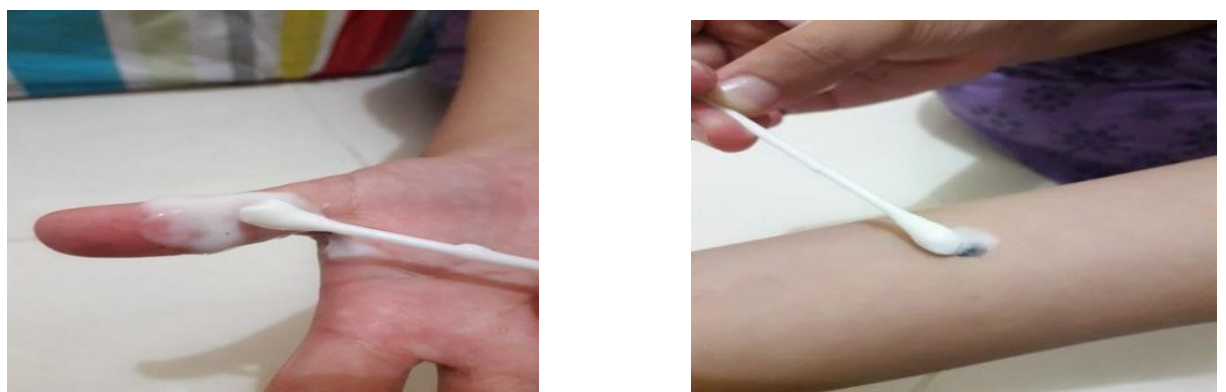


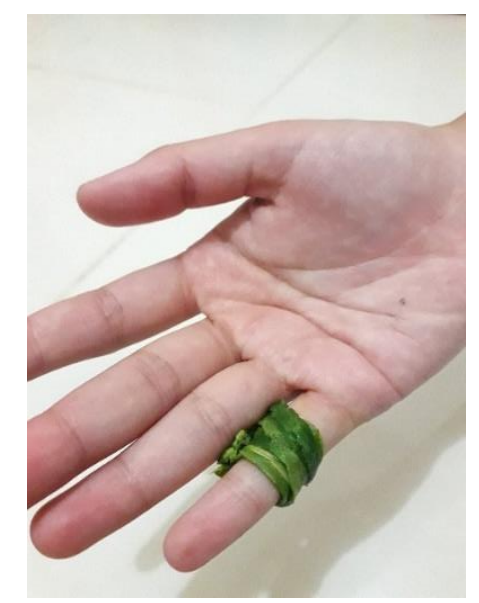

Gambar 11. Pengujian pada tulang yang patah (sukma, 2019)

\section{Hasil Uji Coba}

Tabel 1. Penyembuhan pada kulit dari hari ke-1 hingga hari ke-3

\begin{tabular}{|c|c|c|c|c|}
\hline No. & Pengujian & Hari ke- 1 & Hari ke -2 & Hari ke- 3 \\
\hline 1. & $\begin{array}{l}\text { Untuk } \\
\text { menghilangkan tahi } \\
\text { lalat yang membesar } \\
\text { (A) }\end{array}$ & $\begin{array}{l}6 \text { tetesan } \\
(3 \mathrm{ml})\end{array}$ & $\begin{array}{l}4 \text { tetesan } \\
(2 \mathrm{ml})\end{array}$ & - \\
\hline 2. & $\begin{array}{l}\text { Untuk } \\
\text { menghilangkan } \\
\text { kapalan dan kutil (B) }\end{array}$ & $\begin{array}{l}8 \text { tetesan } \\
(4 \mathrm{ml})\end{array}$ & $\begin{array}{l}6 \text { tetesan } \\
(3 \mathrm{ml})\end{array}$ & - \\
\hline 3. & $\begin{array}{l}\text { Untuk kulit yang } \\
\text { tertusuk duri atau } \\
\text { terkena pecahan kaca } \\
\text { (C) }\end{array}$ & 4 tetes $(2 \mathrm{ml})$ & - & - \\
\hline
\end{tabular}




\begin{tabular}{|l|l|l|l|l|}
\hline & & & & \\
\hline & patah tulang (D) & ranting atau & ranting atau & ranting atau \\
& & dahan & dahan & dahan \\
& yang & yang & yang \\
& dihaluskan. & dihaluskan. & dihaluskan. \\
& Setara & Setara & Setara \\
& dengan & dengan 25 & dengan 20 \\
\hline
\end{tabular}

\section{PEMBAHASAN}

Tanaman patah tulang (Euphorbia tirucalli) merupakan salah satu tanaman yang dapat menyembuhkan berbagai macam penyakit atau gangguan yang dialami pada kulit. Pengobatan dengan tumbuhan daun patah tulang ini sesuai dengan penyembuhan yang dilakukan dan tidak perlu mengeluarkan biaya. Untuk proses penyembuhan menghilangkan tahi lalat yang membesar, menghilangkan kutil, menghilangkan duri yang masuk cukup dengan meneteskan ekstrak atau getah yang ada pada tumbuhan patah tulang (Euphorbia tirucalli). Sedangkan penyembuhan patah tulang ranting atau dahan harus dihaluskan terlbeih dahulu.

Dalam proses penyembuhan sampel yang diperlukan sebanyak $1 \mathrm{~kg}$. Penyembuhan menghilangkan tahi lalat yang membesar untuk hari pertama diperlukan 8 tetes dimana 4 tetes dipakai pada pagi hari dan 4 tetes dipakai pada sore hari apabila dijadikan ke milliliter untuk hari pertama dibutuhkan $4 \mathrm{ml}$, untuk hari kedua sebanyak 6 tetes dimana 3 tetes pada pagi hari dan 3 tetes untuk sore 
hari, apabila dijadikan ke millimeter untuk hari kedua dibutuhkan $3 \mathrm{ml}$, untuk hari ketiga tahi lalat yang membesar sudah menyusut.

Penyembuhan menghilangkan kutil untuk hari pertama diperlukan 6 tetes dimana 3 tetes dipakai pada pagi hari dan 3 tetes dipakai pada sore hari apabila dijadikan ke milliliter untuk hari pertama dibutuhkan $3 \mathrm{ml}$, untuk hari kedua sebanyak 4 tetes dimana 2 tetes pada pagi hari dan 2 tetes untuk sore hari, apabila dijadikan ke millimeter untuk hari kedua dibutuhkan 2 ml, untuk hari ketiga kutil atau kulit yang menebal akan hilang.

Penyembuhan untuk kulit yang tertusuk duri dan pecahan kaca penyembuhannya satu kali saja, dimana saat pemberian 4 tetes getah atau setara dengan $2 \mathrm{ml}$.

Penyembuhan untuk meredakan tulang yang patah untuk hari pertama diperlukan sampel sebanyak 500 gr ranting atau dahan yang dihaluskan dipakai 2 kali sehari, 500 gr apabila dijadikan kedalam bentuk cairan / getah setara dengan $50 \mathrm{ml}$, untuk hari kedua diperlukan sampel sebanyak 250 gr ranting atau dahan yang dihaluskan dipakai 2 kali sehari, 250 gr apabila dijadikan kedalam bentuk cairan / getah setara dengan $25 \mathrm{ml}$, untuk hari ketiga diperlukan sampel sebanyak $200 \mathrm{gr}$ ranting atau dahan yang dihaluskan dipakai 2 kali sehari, 200 gr apabila dijadikan kedalam bentuk cairan / getah setara dengan $20 \mathrm{ml}$ hingga bagian yang patah dapat diredakan dengan halusan dari ranting atau dahan dari tumbuhan patah tulang (Euphorbia tirucalli). 


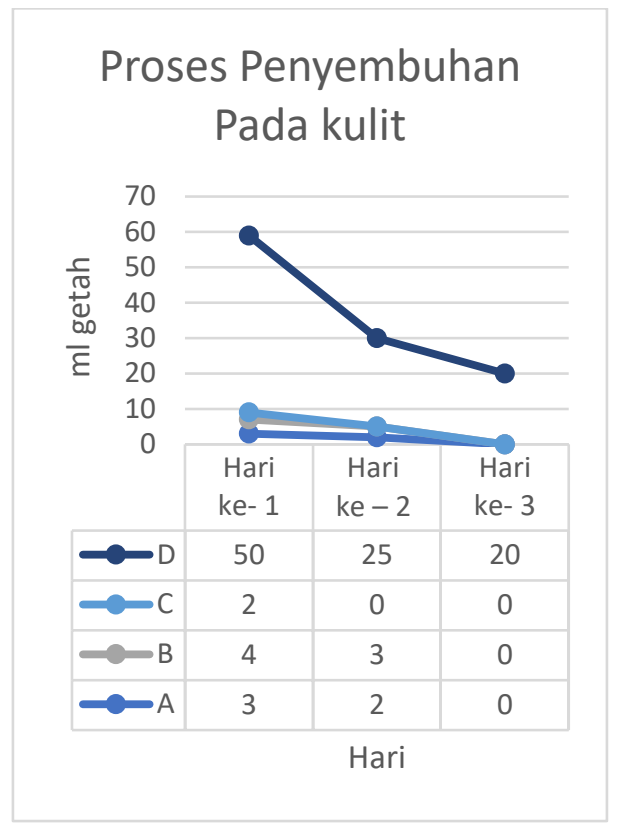

Pada kurva diatas terlihat bahwa dalam 2-3 hari penggunaan tumbuhan patah tulang (Euphorbia tirucalli) dapat menyembuhkan penyakit atau gangguan pada kulit.

Tanaman patah tulang (Euphorbia tirucalli) memang memiliki khasiat yang banyak dalam penyembukan pada kulit, menurut penelitian tanaman patah tulang (Euphorbia tirucalli) ini memiliki kandungan didalamnya berupa glikosida, sapogenin, terpenoid, alkaloid, tanin. Pada getah tanaman patah tulang (Euphorbia tirucalli) ini mengandung senyawa euforbon, taraksasterol, $\alpha$ - Laktuserol, eufol dan senyawa damar. Berikut adalah struktur kimia nya :

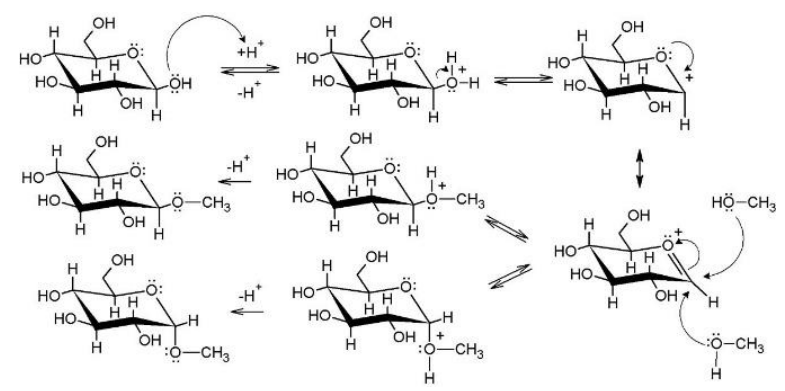

Gambar. Glikosida 


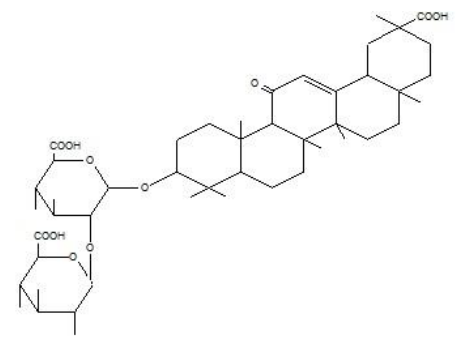

Gambar. Sapogenin<smiles>O=c1c(O)c(-c2ccc(O)c(O)c2)oc2cc(O)ccc12</smiles>

Gambar. Terpenoid<smiles>NC(Cc1ccc(O)c(O)c1)C(=O)O</smiles>

Gambar. Alkaloid

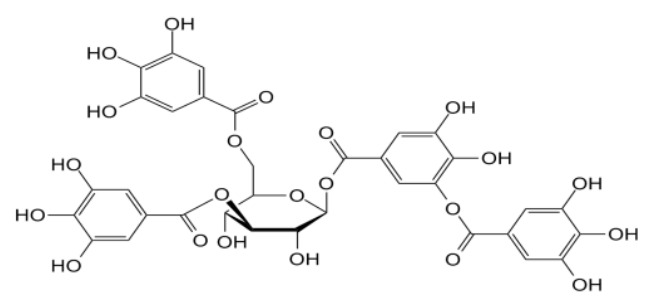

Gambar. Tanin 
Menurut penelitian, tanaman patah tulang (Euphorbia tirucalli) memiliki zat anti bakteri yang terkandung didalam nya adalah tannin. Dimana tannin merupakan zat yang pahit polyphenol yang cepat mengikat atau mengecilkan protein sehingga tannin dapat digunakan sebagai anti bakteri karena tannin mempunyai gugus fenol, sehingga mempunyai sifat-sifat seperti alcohol yang dapat digunakan sebagai antimikroba.

\section{E. KESIMPULAN}

1. Ekstrak dari tanaman patah tulang (Euphorbia tirucalli) diperoleh dari getah dan ranting yang dihaluskan.

2. Getah dari tanaman patah tulang (Euphorbia tirucalli) dapat menghilangkan tahi lalat, menghilangkan kutil atau daging yang membengkak dan mengeluarkan duri atau pecahan kaca yang mengenai kulit karena didalam nya mengandung glikosida, sapogenin, terpenoid, alkaloid, tanin.

3. Dengan adanya tannin yang memiliki sifat seperti alkohol yang bersifat sebagai antiseptik sehingga dapat digunakan sebagai antimikroba.

\section{REFERENSI}

[1] Zainul, R. (2018, August 16). Design and Modification of Copper Oxide Electrodes for Improving Conversion Coefficient Indoors Lights (PV-Cell) Photocells. https://doi.org/10.31227/osf.io/pgn84

[2] Zainul, R. (2018, August 16). Effect of Temperature and Particle Motion against the ability of $\mathrm{ZnO}$ Semiconductor Photocatalyst in Humic Acid. https://doi.org/10.31227/osf.io/wnygb 
[3] Zainul, R. (2018, August 16). Determination of the half-life and the quantum yield of $\mathrm{ZnO}$ semiconductor photocatalyst in humic acid. https://doi.org/10.31227/osf.io/e8a9x

[4] Zainul, R. (2018, August 16). Effect of Temperature and Particle Motion against the ability of $\mathrm{ZnO}$ Semiconductor Photocatalyst in Humic Acid. https://doi.org/10.31227/osf.io/wnygb

[5] Liza, Y. M., Yasin, R. C., Maidani, S. S., \& Zainul, R. (2018, October 9). SOL GEL : PRINCIPLE AND TECHNIQUE (A REVIEW). https://doi.org/10.31227/osf.io/2cuh8

[6] Febriani, S. S., Yolanda, T., Arianti, V. A., \& Zainul, R. (2018, October 12). A Review Solid Stated : Principles and Methode. https://doi.org/10.31227/osf.io/7us4x

[7] Dinata, A. A., Rosyadi, A. M., Hamid, S., \& Zainul, R. (2018, October 15). A Review CHEMICAL VAPOR DEPOSITION : PROCESS AND APPLICATION. https://doi.org/10.31227/osf.io/yfeau

[8] Putri, D. F., Ritonga, H. M., Murdiati, V., \& Zainul, R. (2018, October 15). A REVIEW WHAT IS HYDROTHERMAL ?. https://doi.org/10.31227/osf.io/dm56c

[9] Zainul, R., Alif, A., Aziz, H., Arief, S., Dradjad, S., \& Munaf, E. (2015). Design of photovoltaic cell with copper oxide electrode by using indoor lights. Research Journal Of Pharmaceutical Biological And Chemical Sciences, 6(4), 353-361.

[10]Zainul, R., Alif, A., Aziz, H., \& Arief, S. (2015). Disain Geometri Reaktor Fotosel Cahaya Ruang. Jurnal Riset Kimia, 8(2), 131.

[11]Yuliani, F., \& Zainul, R. (2018, November 13). Analisis Termodinamika Molekul Magnesium Sulphate (MgSO4). https://doi.org/10.31227/osf.io/uxz4y

[12]Zainul, R., Alif, A., Aziz, H., Arief, S., \& s. (2018, August 16). Photoelectrosplitting Water Mechanism at Carbon Electrode Surface using Indoor lights. https://doi.org/10.31227/osf.io/vcxq8 
[13]chaidir, z., Zainul, R., Nurakhbari, D., \& Salim, M. (2018, July 29). Optimization of Spirulina Platensis Culture for Antioxidant Production. https://doi.org/10.17605/OSF.IO/FD6E4

[14]Feronika, N. I., \& Zainul, R. (2018, November 19). Kalium Permanganat: Termodinamika Mengenai Transport Ionik dalam Air. https://doi.org/10.31227/osf.io/g6eyk

[15]Lubis, A. P., \& Zainul, R. (2018, November 5). Interaksi Molekuler Amonium Hidroksida. https://doi.org/10.31227/osf.io/jht3b

[16]Yulis, R., Zainul, R., \& M. (2018, December 10). DESAIN DAN KARAKTERISASI SEL SURYA SISTEM ELEKTRODA TEMBAGA (I) OKSIDA (Cu2O/Al) MODEL PIPA PADA LARUTAN NATRIUM SULFAT (Na2SO4). https://doi.org/10.31227/osf.io/m43js

[17]Rahmadhanty, S., \& Zainul, R. (2018, December 24). DESIGN OF HUMAT ACID SOLID SOLUTION REACTOR THROUGH PHOTOTRANSFORMATION OF COPPER OXIDE (CuO) SEMICONDUCTOR PLATE. https://doi.org/10.31227/osf.io/yhd9x

[18]Putri, G. E., Arief, S., Jamarun, N., Gusti, F. R., \& Zainul, R. (2018, December 10). Microstuctural Analysis and Optical Properties of Nanocrystalline Cerium Oxides Synthesized by Precipitation Method. https://doi.org/10.31227/osf.io/qcz4y

[19]Yanti, C. F., \& Zainul, R. (2018, December 2). A Review Ba (OH)2 : Transpor Ionik pada Barium Hidroksida di dalam Air dengan Konsep Termodinamika. https://doi.org/10.31227/osf.io/fsbq3

[20]Sari, M., \& Zainul, R. (2018, November 19). Kalium Dikromat (K2Cr2O7) $\begin{array}{lll}\text { Spektroskopi dan } & \text { Transpor }\end{array}$ https://doi.org/10.31227/osf.io/w92je

[21]Artika, P. I., \& Zainul, R. (2018, November 19). Potassium Bromide (KBr): Transformasi ionik dan sifat temodinamika dalam Larutan. https://doi.org/10.31227/osf.io/a5hyz

[22]Dwynda, I., \& Zainul, R. (2018, November 19). Boric Acid (H3 (BO3): Recognize The Molecular Interactions in Solutions. https://doi.org/10.31227/osf.io/6wead 
[23]Mawardi, M., Deyundha, D., \& Zainul, R. (2018, April). Characterization of PCC Cement by Addition of Napa Soil from Subdistrict Sarilamak 50 Kota District as Alternative Additional Material for Semen Padang. In IOP Conference Series: Materials Science and Engineering (Vol. 335, No. 1, p. 012034). IOP Publishing.

[24]M., Sanjaya, H., \& Zainul, R. (2018, August 11). Characterization of napa soil and adsorption of $\mathrm{Pb}$ (II) from aqueous solutions using on column method. https://doi.org/10.31227/osf.io/t8fh9

[25]Y., \& Zainul, R. (2018, November 18). SILVER SULFATE (Ag2SO4): MOLECULAR ANALYSIS AND ION TRANSPORT. https://doi.org/10.31227/osf.io/n8g9k

[26]P, O. M., A, L. G., S, A. Y. M., \& Zainul, R. (2018, October 12). A Review Grinding : Teknik dan Prinsip Dasar pada Pengolahan Material. https://doi.org/10.31227/osf.io/trv4q

[27]M., Sanjaya, H., \& Zainul, R. (2018, August 11). Characterization of napa soil and adsorption of $\mathrm{Pb}$ (II) from aqueous solutions using on column method. https://doi.org/10.31227/osf.io/t8fh9

[28]H., Azhar, M., \& Zainul, R. (2018, September 19). THE EFFECTIVENESS OF STRUCTURED INQUIRY BASED MODULE TO IMPROVE MENTAL MODEL OF CONCEPT MOLE. https://doi.org/10.31227/osf.io/ckjtb

[29]Husna, H., \& Zainul, R. (2019, February 3). A Review : Aspek Termodinamika LiNO3 dalam Larutannya. https://doi.org/10.31227/osf.io/45mbd

[30]Alfionita, T., \& Zainul, R. (2019, January 29). Calcium Chloride (CaCl2) : Characteristics and Molecular Interaction in Solution. https://doi.org/10.31227/osf.io/m37xj

[31]Nurfadilah, K. K., \& Zainul, R. (2019, February 3). Kalium Nitrat (KNO3): $\begin{array}{llll}\text { Karakteristik Senyawa dan } & \text { Transpor }\end{array}$ https://doi.org/10.31227/osf.io/dr8ef 
[32]Husna, A. D., \& Zainul, R. (2019, February 4). Analisis Molekular dan $\begin{array}{llll}\text { Karakteristik Hidrogen } & \text { Sianida }\end{array}$ https://doi.org/10.31227/osf.io/7xej9

[33]Shafitri, M., \& Zainul, R. (2019, February 3). Vanadium Pentaoksida (V2O5) : Termodinamika Molecular dan Interaksi Ion dalam Larutan. https://doi.org/10.31227/osf.io/jgmvd

[34]Delvi, I. P., \& Zainul, R. (2019, February 3). Mercury (II) Nitrate (Hg (NO3)2): Interaksi Molekul dan Adsorpsi $\mathrm{Hg}$ dengan Karbon Aktif. https://doi.org/10.31227/osf.io/eqyax

[35]Jumalia, R., \& Zainul, R. (2019, February 3). Natrium Karbonat : Termodinamika dan Transport Ion. https://doi.org/10.31227/osf.io/y2vq9

[36]Kristy, D. P., \& Zainul, R. (2019, February 3). Analisis Molekular dan Transpor Ion Natrium Silikat. https://doi.org/10.31227/osf.io/8ac4m

[37]Sari, E. S. J., \& Zainul, R. (2019, January 31). Nitrogen Triflorida (NF3) : $\begin{array}{llll}\text { Termodinamika dan } & \text { Transpor }\end{array}$ https://doi.org/10.31227/osf.io/3nzrh

[38]Zainul, R. (2019, January 15). f. https://doi.org/10.31227/osf.io/75pdj

[39]Warlinda, Y. A., \& Zainul, R. (2019, January 29). Asam Posfat (H3PO4): Ionic Transformation of Phosphoric Acid in Aqueous Solution. https://doi.org/10.31227/osf.io/s3y8v

[40]Hakimi, A., \& Zainul, R. (2019, January 31). Asam Arsenat (H3AsO4) : Analisis Molekular dan Karakteristik Senyawa. https://doi.org/10.31227/osf.io/e486z

[41]Zainul, R. and Wardani, S. (2019) “The Hydrogen Generator Performance of Sandwich Designed 4/4 Al-Cu Plates", EKSAKTA: Berkala Ilmiah Bidang MIPA, 20(1), pp. 100-104. doi: 10.24036/eksakta/vol20-iss1/177.

[42]Yanuar, F., Tillah, M. and Devianto, D. (2018) "Modeling of Human Development Index Using Ridge Regression Method”, EKSAKTA: Berkala Ilmiah Bidang MIPA, 19(2), pp. 1-11. doi: 10.24036/eksakta/vol19iss $2 / 134$.

[43]Enjelina, W., Mansyurdin, M. and Meideliza, T. (2018) "Analysis of Nepenthes Hybrids in Bukik Taratak West Sumatra by RAPD 
Technique", EKSAKTA: Berkala Ilmiah Bidang MIPA, 19(2), pp. 12-20. doi: 10.24036/eksakta/vol19-iss2/137.

[44]Syafei, N., Hidayat, D., Emilliano, E. and Men, L. (2018) “Analysis Cracking Corrosion on Carbon Steel Pipes API 5L-X65 In Solution 7700 $\mathrm{ml}$ Aquades, $250 \mathrm{ml}$ Acetic Acid and $50 \mathrm{ml}$ Ammonia with Gas CO2 and $\mathrm{H} 2 \mathrm{~S}$ in Saturation Condition", EKSAKTA: Berkala Ilmiah Bidang MIPA, 19(2), pp. 21-31. doi: 10.24036/eksakta/vol19-iss2/138.

[45]Santoso, B., Setianto, S., Hasanah, M., Wijatmoko, B., Supriyana, E. and Mohammad, H. (2018) "Mitigation of Land Movement using Self Potential Method in Ling-Anjung Region Sumedang Regency", EKSAKTA: Berkala Ilmiah Bidang MIPA, 19(2), pp. 32-39. doi: 10.24036/eksakta/vol19iss $2 / 141$.

[46]Parbuntari, H., Prestica, Y., Gunawan, R., Nurman, M. and Adella, F. (2018) "Preliminary Phytochemical Screening (Qualitative Analysis) of Cacao Leaves (Theobroma cacao L.)", EKSAKTA: Berkala Ilmiah Bidang MIPA, 19(2), pp. 40-45. doi: 10.24036/eksakta/vol19-iss2/142.

[47]Dinata, M. and Soehardi, F. (2018) "Factor Analysis of Physics Chemistry Waters that Affects Damage Safety Cliff on the Outskirts of River Siak”, EKSAKTA: Berkala Ilmiah Bidang MIPA, 19(2), pp. 46-49. doi: 10.24036/eksakta/vol19-iss2/143.

[48]Harahap, F. and Lubis, L. (2018) “Analysis of Heavy Metals Distribution in the River Town of Hamasaki's Rod Padangsidimpuan", EKSAKTA: Berkala Ilmiah Bidang MIPA, 19(2), pp. 50-56. doi: 10.24036/eksakta/vol19-iss2/149.

[49]Badrulfalah, B., Irianingsih, I. and Joebaedi, K. (2018) "Some Operations on Mixed Monotone Operator in Banach Spaces", EKSAKTA: Berkala Ilmiah Bidang MIPA, 19(2), pp. 57-61. doi: 10.24036/eksakta/vol19iss $2 / 150$.

[50]Joebaedi, K., Parmikanti, K. and Badrulfalah, B. (2018) "First Order Space Time Autoregressive Stationary Model on Petroleum Data", EKSAKTA: Berkala Ilmiah Bidang MIPA, 19(2), pp. 62-69. doi: 10.24036/eksakta/vol19-iss2/152. 
[51]Sofyanita, S. and Octaria, Z. (2018) "Fenthion Compound Degradation in the Pesticide Bayleton 500 ec in Sonolysis, Ozonolysis and Sonozolysis with Addition of TiO2-anatase", EKSAKTA: Berkala Ilmiah Bidang MIPA, 19(2), pp. 70-79. doi: 10.24036/eksakta/vol19-iss2/153.

[52]Vauzia, V. and Gusmira, E. (2018) "The Response of Jabon Seeds Germination (Anthocephalus cadamba (Roxb.)Miq.) against the Duration of Combustion and Illumination", EKSAKTA: Berkala Ilmiah Bidang MIPA, 19(2), pp. 80-87. doi: 10.24036/eksakta/vol19-iss2/154.

[53]Horiza, H. (2018) "The influence of the use of activated carbon Fibres of the cane Against the drop in Salinity In the well Dig In RT 003 RW 006 Village Cape Town Unggat Tanjungpinang Year 2017”, EKSAKTA: Berkala Ilmiah Bidang MIPA, 19(1), pp. 1-6. doi: 10.24036/eksakta/vol19iss $1 / 97$.

[54]Syafei, N. (2018) "Riset Material ANALISA FENOMENA KOROSI PELAT PIPA BAJA KARBON API 5L-X65 DALAM LARUTAN 7900 ML AIR LAUT DAN 100 ML AMONIAK PADA KONDISI GAS CO2 DAN H2S JENUH PADA SUHU RUANG.”, EKSAKTA: Berkala Ilmiah Bidang MIPA, 19(1), pp. 7-13. doi: 10.24036/eksakta/vol19-iss 1/83.

[55]Ruswandi, R. (2018) “Determination of Fructose Content resulted by Inulin Hydrolysis with DNS as Oxidizer", EKSAKTA: Berkala Ilmiah Bidang MIPA, 19(1), pp. 14-23. doi: 10.24036/eksakta/vol19-iss1/102.

[56]Prabowo, H. (2018) "PENYELIDIKAN KELAYAKAN KIMIA DAN PENYEBARAN CADANGAN PASIR BESI DAERAH TIKU KABUPATEN AGAM UNTUK BAHAN BAKU SEMEN PADA PT. SEMEN PADANG”, EKSAKTA: Berkala Ilmiah Bidang MIPA, 19(1), pp. 39-42. doi: 10.24036/eksakta/vol19-iss1/121.

[57]Rizki Saputra, M. and Sumarmin, R. (2018) "PENGARUH EKSTRAK DAUN SIRIH MERAH (Piper crocatum Ruiz \& Pav.) TERHADAP GLUKOSA DARAH MENCIT (Mus musculus L.) JANTAN YANG DIINDUKSI SUKROSA", EKSAKTA: Berkala Ilmiah Bidang MIPA, 19(1), pp. 43-55. doi: 10.24036/eksakta/vol19-iss 1/124. 
[58]Hidayani, T. (2018) "GRAFTING POLIPROPILENA DENGAN MALEAT ANHIDRIDA SEBAGAI PENGIKAT SILANG DENGAN INISIATOR BENZOIL PEROKSIDA”, EKSAKTA: Berkala Ilmiah Bidang MIPA, 19(1), pp. 56-62. doi: 10.24036/eksakta/vol19-iss1/127.

[59]Badrulfalah, B. (2018) "SUB RUANG TUTUP TOPOLOGI HASIL KALI RUANG METRIK KERUCUT”, EKSAKTA: Berkala Ilmiah Bidang MIPA, 19(1), pp. 63-67. doi: 10.24036/eksakta/vol19-iss1/128.

[60]Advinda, L. (2018) "PERTUMBUHAN STEK HORIZONTAL BATANG JARAK PAGAR (Jatropha curcas L.) YANG DIINTRODUKSI DENGAN PSEUDOMONAD FLUORESEN", EKSAKTA: Berkala Ilmiah Bidang MIPA, 19(1), pp. 68-75. doi: 10.24036/eksakta/vol19-iss1/129.

[61]Welyyanti, D. (2018) "BEBERAPA SYARAT CUKUP UNTUK BILANGAN KROMATIK LOKASI HINGGA PADA GRAF TAK TERHUBUNG”, EKSAKTA: Berkala Ilmiah Bidang MIPA, 19(1), pp. 7682. doi: 10.24036/eksakta/vol19-iss1/130.

[62]Rizal, Y. (2018) “DIAGONALISASI BENTUK KUADRATIK IRISAN KERUCUT”, EKSAKTA: Berkala Ilmiah Bidang MIPA, 19(1), pp. 83-90. doi: 10.24036/eksakta/vol19-iss1/132.

[63]Sanjaya, H. (2018) "DEGRADASI METIL VIOLET MENGGUNAKAN KATALIS ZnO-TiO2 SECARA FOTOSONOLISIS”, EKSAKTA: Berkala Ilmiah Bidang MIPA, 19(1), pp. 91-99. doi: 10.24036/eksakta/vol19iss $1 / 131$.

[64]Sumarmin, R. (2018) "Pengaruh Ekstrak Kulit Buah Manggis (Garcinia mangostana L.) terhadap Histologis Pankreas Mencit (Mus musculus L. Swiss Webster) yang Diinduksi Sukrosa", EKSAKTA: Berkala Ilmiah Bidang MIPA, 19(1), pp. 100-112. doi: 10.24036/eksakta/vol19-iss1/123.

[65]Multahadah, C. (2018) “ANALISIS KLASIFIKASI AKREDITASI SMA/MA BERDASARKAN FAKTOR-FAKTOR YANG MEMPENGARUHI SE PROVINSI JAMBI DENGAN RLTOG”, EKSAKTA: Berkala Ilmiah Bidang MIPA, 19(1), pp. 113-117. doi: 10.24036/eksakta/vol19-iss1/116. 
[66]Hidayat, D. (2018) "ANALISIS RESPON PENGONTROL ON-OFF PADA KENDALI UMPAN BALIK SISTEM FISIS ELEKTRONIK", EKSAKTA: Berkala Ilmiah Bidang MIPA, 19(1), pp. 118124. doi: 10.24036/eksakta/vol19-iss1/119.

[67]Putri, D., Fifendy, M. and putri, M. (2018) “DIVERSITAS BAKTERI ENDOFIT PADA DAUN MUDA DAN TUA TUMBUHAN ANDALEH (Morus macroura miq.)", EKSAKTA: Berkala Ilmiah Bidang MIPA, 19(1), pp. 125-130. doi: 10.24036/eksakta/vol19-iss1/122.

[68]Santoso, B. (2018) “IDENTIFIKASI AKUIFER MENGGUNAKAN METODE GEOLISTRIK RESISTIVITAS DI DAERAH BEBANDEM, KARANG ASEM, BALI", EKSAKTA: Berkala Ilmiah Bidang MIPA, 19(1), pp. 24-34. doi: 10.24036/eksakta/vol19-iss1/101.

[69]Joebaedi, K. (2018) "MODEL STAR(1;1) PADA DATA PRODUKTIVITAS TEH", EKSAKTA: Berkala Ilmiah Bidang MIPA, 19(1), pp. 35-38. doi: 10.24036/eksakta/vol19-iss1/118.

[70]Chatri, M., Mansyurdin, M., Bakhtiar, A. and Adnadi, P. (2017) "PERBANDINGAN KOMPONEN MINYAK ATSIRI ANTARA DAUN MUDA DAN DAUN DEWASA PADA HYPTIS SUAVEOLENS (L.)POIT”, EKSAKTA: Berkala Ilmiah Bidang MIPA, 18(02), pp. 1-12. doi: 10.24036/eksakta/vol18-iss02/41.

[71]Sanjaya, H. (2017) "DEGRADASI METHYLENE BLUE MENGGUNAKAN KATALIS ZnO-PEG DENGAN METODE FOTOSONOLISIS”, EKSAKTA: Berkala Ilmiah Bidang MIPA, 18(02), pp. 21-29. doi: 10.24036/eksakta/vol18-iss02/45.

[72]Samah, S. (2017) “KARAKTERISASI PLASTIK BIODEGRADABEL DARI LDPE-g-MA DAN PATI TANDAN KOSONG SAWIT”, EKSAKTA: Berkala Ilmiah Bidang MIPA, 18(02), pp. 30-38. doi: 10.24036/eksakta/vol18-iss02/48.

[73]Ningsih, S. K. (2017) "SINTESIS DAN KARAKTERISASI NANOPARTIKEL ZnO DOPED Cu2+ MELALUI METODA SOLGEL", EKSAKTA: Berkala Ilmiah Bidang MIPA, 18(02), pp. 39-51. doi: 10.24036/eksakta/vol18-iss02/51. 
[74]Saluza, I. (2017) "MODEL ESTIMASI GARCH DALAM MENGUKUR KINERJA NILAI TUKAR RUPIAH”, EKSAKTA: Berkala Ilmiah Bidang MIPA, 18(02), pp. 52-61. doi: 10.24036/eksakta/vol18-iss02/53.

[75]Prihatini, R. (2017) "PEMANFAATAN AIR KELAPA UNTUK MENINGKATKAN PERTUMBUHAN AKAR STEK TUNAS AKSILAR Andrographis paniculata Nees", EKSAKTA: Berkala Ilmiah Bidang MIPA, 18(02), pp. 62-68. doi: 10.24036/eksakta/vol18-iss02/54.

[76]Huda, N. (2017) "PENGARUH EKSTRAK SAMBILOTO (Andrographis paniculata Nees.) TERHADAP SIKLUS ESTRUS MENCIT (Mus musculus L. Swiss Webster)", EKSAKTA: Berkala Ilmiah Bidang MIPA, 18(02), pp. 69-76. doi: 10.24036/eksakta/vol18-iss02/55.

[77]Saiya, A. (2017) “ANALISIS RESIDU KLORPIRIFOS DALAM SAYURAN KUBIS DENGAN METODE HPLC DI BEBERAPA PASAR TRADISIONAL DI SULAWESI UTARA”, EKSAKTA: Berkala Ilmiah Bidang MIPA, 18(02), pp. 77-85. doi: 10.24036/eksakta/vol18-iss02/57.

[78]Rahmi H.G, I. (2017) “TELAAH FAKTOR-FAKTOR YANG MEMPENGARUHI STATUS GIZI BALITA DI KOTA PADANG BERDASARKAN BERAT BADAN PER TINGGI BADAN MENGGUNAKAN METODE CART”, EKSAKTA: Berkala Ilmiah Bidang MIPA, 18(02), pp. 86-99. doi: 10.24036/eksakta/vol18-iss02/59.

[79]Hartono, A. (2017) “APLIKASI SENSOR PVDF UNTUK PENGUKURAN PERGESERAN SUDUT”, EKSAKTA: Berkala Ilmiah Bidang MIPA, 18(02), pp. 100-106. doi: 10.24036/eksakta/vol18-iss02/60. [80]Sari, A. (2017) "POTENSI ANTIOKSIDAN ALAMI PADA EKSTRAK DAUN JAMBLANG (Syzigium cumini (L.) Skeels)", EKSAKTA: Berkala Ilmiah Bidang MIPA, 18(02), pp. 107-112. doi: 10.24036/eksakta/vol18iss02/61.

[81]Syafei, N. (2017) “ANALISA FENOMENA KOROSI PELAT PIPA BAJA KARBON API 5L-X65 DALAM LARUTAN 250 ML ASAM ASETAT DAN 4750 ML AQUADES PADA KONDISI GAS CO2 DAN H2S JENUH PADA SUHU RUANG", EKSAKTA: Berkala Ilmiah Bidang MIPA, 18(02), pp. 113-120. doi: 10.24036/eksakta/vol18-iss02/63. 
[82]Susilaningrum, D. (2017) "PEMODELAN REGRESI LOGISTIK PADA FAKTOR YANG MEMPENGARUHI PHBS PADA RUMAH TANGGA PENDERITA TBC DI PESISIR SURABAYA”, EKSAKTA: Berkala Ilmiah Bidang MIPA, 18(02), pp. 121-128. doi: 10.24036/eksakta/vol18-iss02/65. [83]Afandi, N. (2017) “APLIKASI FUZZY c-MEANS CLUSTERINGUNTUK MENGELOMPOKKAN DATA GEMPABUMI DI PROVINSI BENGKULU”, EKSAKTA: Berkala Ilmiah Bidang MIPA, 18(02), pp. 129136. doi: 10.24036/eksakta/vol18-iss02/66.

[84]Mulia, M. (2017) “ISOLASI KUMARIN DARI KULIT BUAH LIMAU SUNDAI (Citrus nobilis Lour)", EKSAKTA: Berkala Ilmiah Bidang MIPA, 18(02), pp. 137-145. doi: 10.24036/eksakta/vol18-iss02/70.

[85]Murni, D. (2017) "PERBANDINGAN DAN KARAKTERISTIK BEBERAPATES KONVERGENSI PADA DERET TAK HINGGA”, EKSAKTA: Berkala Ilmiah Bidang MIPA, 18(02), pp. 146-157. doi: 10.24036/eksakta/vol18-iss02/71.

[86]Sudrajat, R. (2017) “TINJAUAN TENTANG KETERKAITAN PARAMETER DENGAN MODEL REGRESI MULTIVARIAT PADA KOLAM IKAN TERTUTUP”, EKSAKTA: Berkala Ilmiah Bidang MIPA, 18(02), pp. 158-163. doi: 10.24036/eksakta/vol18-iss02/72.

[87]Tutuarima, T. (2017) “SIFAT FISIK DAN KIMIA MARMALADE JERUK KALAMANSI (Citrus microcarpa) : KAJIAN KONSENTRASI PEKTIN DAN SUKROSA Physical and Chemical Properties of Marmalade Citrus of Calamondin (Citrus microcarpa) : Study of Pectin and Sucrose Concentrations", EKSAKTA: Berkala Ilmiah Bidang MIPA, 18(02), pp. 164-172. doi: 10.24036/eksakta/vol18-iss02/73.

[88]Setianto, S. (2017) “ANALISA KUANTITATIF CAMPURAN SENYAWA OKSIDA SEBAGAI DASAR IDENTIFIKASI KANDUNGAN BAHAN SUMBER DAYA ALAM Studi Kasus : Kandungan Mineral pada Pasir Besi di Pesisir Pantai Selatan, Jawa Barat”, EKSAKTA: Berkala Ilmiah Bidang MIPA, 18(02), pp. 173-177. doi: 10.24036/eksakta/vol18-iss02/74. 
[89]Hidayat, D. (2017) "IMPLEMENTASI PENGONTROL PID PADA MODEL FISIS ELEKTRONIK", EKSAKTA: Berkala Ilmiah Bidang MIPA, 18(02), pp. 178-185. doi: 10.24036/eksakta/vol18-iss02/75.

[90]Badrulfalah, B. (2017) "INTERVAL KEKONTRAKTIFAN PEMETAAN PADA RUANG BANACH”, EKSAKTA: Berkala Ilmiah Bidang MIPA, 18(02), pp. 187-190. doi: 10.24036/eksakta/vol18-iss02/76.

[91]Irawan, W. (2017) "PENENTUAN HARGA OPSI DENGAN MODEL BLACK-SCHOLES MENGGUNAKAN METODE BEDA HINGGA CENTER TIME CENTER SPACE (CTCS)", EKSAKTA: Berkala Ilmiah Bidang MIPA, 18(02), pp. 191-199. doi: 10.24036/eksakta/vol18-iss02/77. [92]Nasir, M. (2017) "PENGARUH WAKTU HIGH ENERGY MILLING TERHADAP KARAKTERISTIK NANOKAOLIN CAPKALA ASAL KALIMANTAN BARAT”, EKSAKTA: Berkala Ilmiah Bidang MIPA, 18(02), pp. 200-209. doi: 10.24036/eksakta/vol18-iss02/78.

[93]Amananti, W. (2017) “ANALISIS MIKROSTRUKTUR LAPISAN TIPIS TiO2:ZnO YANG DIDEPOSISIKAN DIATAS SUBTRAT KACA DENGAN METODE SPRAY COATING UNTUK DEGRADASI LIMBAH ZAT WARNA", EKSAKTA: Berkala Ilmiah Bidang MIPA, 18(02), pp. 210-215. doi: 10.24036/eksakta/vol18-iss02/81.

[94]Altway, Ali, Winardi, Sugeng, Rachimoellah, M . (2012) “Aplikasi Packet Diffusion Model untuk Menganalisis Pengaruh Fenomena Micromixing terhadap Jalannya Reaksi Kimia Paralel di dalam Reaktor Tangki reraduk Kontinyu dengan Aliran Umpan Terpisah", Majalah Forum Teknik UGM , 28 (2). (2004) .

[95]Retnowati, Diah Susetyo . (2011) "PEMUTIHAN ENCENG GONDOK MENGGUNAKAN $\mathrm{H}_{2} \mathrm{O}_{2}$ DENGAN KATALISATOR NATRIUM BIKARBONAT" , Dept. of Chemical Engineering, Diponegoro University , 12(1), Juni 2008.

[96]Agral, Omega, Fatimawali, Fatimawali, Yamlean, Paulina V.Y, Supriati, Hamidah Sri . (2013) . "FORMULASI DAN UJI KELAYAKAN SEDIAAN KRIM ANTI INFLAMASI GETAH TANAMAN PATAH TULANG (Euphorbia tirucalli L)”, PHARMACON , 2(3). 
[97]Sesilia I. Napa, Theo Da Cunha, Yohanes Buang . (2001) “Antibacterial Activities of Ranting Patah Tulang (Euphorbia tirucalli)", Extract: Short Communication. Journal of Applied Chemical Science, 2(1).

[98]Toana, Moh. Hibban, Nasir, Burhanuddin . (2012) “STUDI BIOAKTIVITAS DAN ISOLASI SENYAWA BIOAKTIF TUMBUHAN Euphorbia tirucalli L. (EUPHORBIACEAE) SEBAGAI INSEKTISIDA BOTANI ALTERNATIF “, AGROLAND, 17(1).

[99]Setiorini, Melina Scandinovita, Soegihardjo, C.J., Atmodjo, Kianto . (2016) "POTENSI ANTIMIKROBIA KRIM EKSTRAK RANTING PATAH TULANG (Euphorbia tirucalli Linn.) TERHADAP Propionibacterium acnes ATCC 11827 DAN Candida albicans ATCC 24433”, Sanata Dharma University, 11(2).

[100] Oratmangun, Sandriani A. (2014) "UJI TOKSISITAS EKSTRAK TANAMAN PATAH TULANG (Euphorbia tirucalli L.) TERHADAP Artemia salina DENGAN METODE BRINE SHRIMP LETHALITY TEST (BSLT) SEBAGAI STUDI PENDAHULUAN POTENSI ANTI KANKER", PHARMACON, 3(3).

[101] Baud, Grace S., Sangi, Meiske S., Koleangan, Harry S.J. (2014) “ANALISIS SENYAWA METABOLIT SEKUNDER DAN UJI TOKSISITAS EKSTRAK ETANOL BATANG TANAMAN PATAH TULANG (Euphorbia tirucalli L.) DENGAN METODE Brine Shrimp Lethality Test (BSLT)", Sam Ratulangi University, 14(2).

[102] Kalangi, Sonny J R . (2013) “KHASIAT MADU PADA PENYEMBUHAN LUKA KULIT”, JURNAL , 4(3).

[103] Alkalili, Dina . (2018) “:EFEKTIVITAS DAN KECEPATAN REAKSI EKSTRAK TUMBUHAN PATAH TULANG (Euphorbia tirucalli) TERHADAP KEMATIAN LARVA NYAMUK Aedes aegypti SEBAGAI PENGEMBANGAN EKOTOKSIKOLOGI", JURNAL PENELITIAN DAN KAJIAN ILMIAH KESEHATAN POLITEKNIK MEDICA FARMA HUSADA MATARAM, 4(2).

[104] Kurniawati, Y., Amalita, N. and Syafriandi, S. (2017) "PENERAPAN IMPORTANCE PERFORMANCE ANALYSIS DALAM MENILAI 
KEPUASAAN STAKEHOLDER TERHADAP KINERJA PKL MAHASISWA D3 STATISTIKA”, EKSAKTA: Berkala Ilmiah Bidang MIPA, 18(01), pp. 1-11. doi: 10.24036/eksakta/vol18-iss01/4.

[105] Alfian Noor . (2010) . "Kemungkinan Penggunaan Poliprenol untuk Taksonomi Kimia Tanaman”, HAYATI Journal of Biosciences, 5(3).

[106] Anhar, A., Sumarmin, R., \& Zainul, R. (2016). Measurement of Glycemic Index of West Sumatera Local Rice Genotypes for Healthy Food Selection. Journal of Chemical and Pharmaceutical Research, 8(8), 10351040 .

[107] Zainul, R. (2015). Disain dan Modifikasi Kolektor dan Reflektor Cahaya pada Panel Sel Surya Al/Cu2O-Gel Na2SO4.

[108] Zainul, R., Oktavia, B., \& Dewata, I. efendi, j.(2017, February 4). Studi Dinamika Molekular dan Kinetika Reaksi pada Pembelahan Molekul Air untuk Produksi Gas Hidrogen.

[109] Desy Kurniawati, I., Harmiwati, S. S., Chaidir, Z., \& Munaf, E. Rahmiana Zein, Hermansyah Aziz, Rahadian Zainul. 2015. Biosorption of Pb (II) from Aqueous Solutions Using Column Method by Lengkeng (Euphoria logan lour) Seed and Shell. Journal of Chemical and Pharmaceutical Research, 7 , 872-7.

[110] Fatimah, P., Jumalia, R., Novianti, E. R., \& Zainul, R. (2018). A REVIEW Teknik Blended: Prinsip dan Dasar-Dasar.

[111] Zainul, R., Alif, A., Aziz, H., \& Arief, S. s.(2015, October 22). Photoelectrosplitting Water Mechanism at Carbon Electrode Surface using Indoor lights.

[112] Kurniawati, D., Lestari, I., Harmiwati, S. S., Chaidir, Z., Munaf, E., Zein, R., ... \& Zainul, R. (2015). Biosorption of $\mathrm{Pb}$ (II) from aqueous solutions using column method by lengkeng (Euphoria logan lour) seed and shell. Journal of Chemical and Pharmaceutical Research, 7(12), 872-877.

[113] Zainul, R., \& Dewata, I. (2015). Determination of pH-BOD-COD and degradation in batang arau watersheds at Padang city.

[114] Chaidir, Z., Zainul, R., Nurakhbari, D., \& Salim, M. (2016). Optimization of Spirulina Platensis Culture for Antioxidant Production. 
[115] Zainul, R., Effendi, J., \& Mashuri, M. (2019). Phototransformation of Linear Alkylbenzene Sulphonate (LAS) Surfactant Using ZnO-CuO Composite Photocatalyst. KnE Engineering, 1(2), 235-247.

[116] DADANG ., BUDI SAPUTRO , KANJU OHSAWA . 2012 . “Aktivitas Minyak dan Serbuk Enam Spesies Tumbuhan terhadap Peneluran dan Mortalitas Callosobruchus sp. (Coleoptera: Bruchidae)", Jurnal Entomologi Indonesia, 3(2).

[117] B Paul Niola $\quad 2010$

Ulas Balik Regulasi osmosis pada tumbuhan tinggi”, HAYATI Journal of Biosciences, 3(1).

[118] Yeni, Yeni Dianita, Djannah, Sitti Nur , Nurani, Laela Hayu . 2010 . "UJI AKTIVITAS ANTIBAKTERI INFUSA DAUN SIRSAK (Annona muricata L.) SECARA in Vitro TERHADAP Staphylococcus aureus ATCC 25923 dan Escherichia coli ATCC 35218 SERTA PROFIL KROMATOGRAFI LAPIS TIPISNYA”, Jurnal Kesehatan Masyarakat (Journal of Public Health), 4(3).

[119] Arum, Rifah Hestyani, Satiawihardja, Budiatman, Kusumaningrum, Harsi D. 2014 . “AKTIVITAS ANTIBAKTERI GETAH PEPAYA KERING TERHADAP Staphylococcus aureus PADA DANGKE [Antibacterial Activity of Dried Papaya Latex toward Staphylococcus aureus in Dangke]", Jurnal Teknologi Dan Industri Pangan, 25(1).

[120] Sumardiyono, Christanti, Hartono, Sedyo, Nasrun, Nasrun, Sukamto, Sukamto . 2013 .Pengendalian Penyakit Budok dengan Fungisida dan Deteksi Residu pada Daun Nilam”, Jurnal Fitopatologi Indonesia, 9(3).

[121] Hapsari Murdianingtyas, Didik Indradewa, dan Nikardi Gunadi, Putri . 2012 . "Pengaruh Pengurangan Daun Terhadap Pertumbuhan dan Hasil Dua Varietas Paprika (Capsicum annum var.Grossum) Hidroponik”, Vegetalika, $1(3)$.

[122] Ratri Astuti, Rohlan Rogomulyo, Sri Muhartini, Ikhsanah . 2012 . "Pertumbuhan Tanaman dan Hasil Umbi Daun Dewa (Gynura procumbens Back.) pada Berbagai Intensitas Cahaya dan Pemangkasan Daun", Vegetalika, 1 (4) 
[123] Yuniaryaningsih. S, I. A. . 2012 . "PEMERIKSAAN MIKROSKOPIK GETAH PARU PADA JENASAH YANG DIDUGA TENGGELAM DI RSUP SANGLAH TAHUN 2010”, E-Jurnal Medika Udayana, 1(1).

[124] Dorly, „,Wulandari, Indah, Tjitrosemito, Soekisman, Poerwanto, Roedhy, Efendi, Darda . 2011 . "Studi Pemberian Kalsium untuk Mengatasi Getah Kuning pada Buah Manggis (Garcinia mangostana L.)”, Jurnal Agronomi Indonesia (Indonesian Journal of Agronomy), 39(1).

[125] Hong, Ng Tze, Ibrahim, Nor Hayati . 2012 . "EXTRACTION AND CHARACTERIZATION OF MUCILAGE FROM LEAVES OF Pereskia bleo (ROSE CACTUS) [Ekstraksi dan Karakterisasi dari Getah Daun Kaktus Mawar (Pereskia bleo)]”, Jurnal Teknologi Dan Industri Pangan, 23(2).

[126] Cahyono, S. Andy, Nugroho, Nunung Puji Indrajaya, Yonky . 2007 . " Alokasi Pengeluaran Rumah Tangga Penyadap Getah Pinus di Desa Somagede, Kabupaten Kebumen Jawa Tengah”, Jurnal Ilmu Kehutanan, $1(1)$.

[127] Rahman, Erwid Fatchur . 2010 . "Efektivitas Ekstrak Daun Dewa (Gynura Pseudochina (Lour.) Dc) Terhadap Pertumbuhan Candida Albicans Pada Plat Dasar Gigi Tiruan Resin Akrilik”, Majalah Ilmiah Sultan Agung, $48(123)$.

[128] Martiningsih, N.G.A. Gde Eka, Widnyana, I Ketut, Setiyono, Tri Djoko, Anom, I Gusti Ngurah . 2012 . "SANITASI KEBUN DAN PEMUPUKAN ORGANIK PADA TANAMAN MANGGIS (Garcinia mangostana L.) GUNA PENGENDALIAN GETAH KUNING”, Jurnal Ngayah, 3(4).

[129] Amorosidi, Muhamad, Malau, Viktor, Maryono, Agus . 2010 . "REKAYASA TEKNOLOGI PEMILIN TALI BATANG ECENG GONDOK DENGAN MESIN PEMILIN", Jurnal Sistem Teknik, 1.

[130] Cornelis, Remigildus . 2011 . "KAJIAN SIFAT MEKANIKAL DAN KOMPOSISI ELEMEN BATANG PROFIL L BERBAHAN FERROCEMENT SEBAGAI MATERIAL ALTERNATIF PENGGANTI KAYU DAN BAJA”, Jurnal Teknik Sipil, 1 (2). 
[131] Cornelis, Remigildus . 2012 . "KAJIAN EXPERIMENTAL DAN NUMERIK DESAIN PERANCANGAN ELEMEN BATANG PROFIL L BERBAHAN FERROCEMENT SEBAGAI PENGGANTI ELEMEN RANGKA KUDA-KUDA ATAP RINGAN BERBAHAN KAYU ATAU BERBAHAN BAJA", Jurnal Teknik Sipil, 1 (3).

[132] Utami, Listiatie Budi . 2004 . "EFEKTIVITAS SERAI WANGI (Cymbopogon nardus Linn) SEBAGAI BIO FUNGISIDA PADA PENGENDALIAN Sclerotium rolfsii Sacc PENYEBAB BUSUK PANGKAL BATANG PADA TANAMAN CABAI MERAH (Capsicum annuum L)", PROSIDING SEMINAR NASIONAL.

[133] Paramita, Toekidjo, Setyastuti Purwanti, Pradnya . 2012 . "Kesesuaian Sambungan Mini Tiga Kultivar Durian (Durio zibethinus L. ex Murray) dengan Batang Bawah Berbagai Umur", Vegetalika, 1 (2).

[134] Sadono, Ronggo, Trisnomo, Muhammad Dimas , Askar . 2009 . "Model Lengkung Bentuk Batang (Taper Curve) Pohon Jati (Tectona Grandis)”, Jurnal Ilmu Kehutanan, 3(1).

[135] Ismalia Afriani . 2007 . "ANALISIS PEMASARAN GETAH DAMAR MATA KUCING (Shorea javanica) DI KABUPATEN LAMPUNG BARAT”, Jurnal Sosio Ekonomika (Journal of Socio Economics), 13(2).

[136] Pratama, Nanda Budya , Kistini, Kistini . 2013 . “AKTIVITAS INDUSTRI KERAJINAN TOPENG KAYU DI DESA WISATA BOBUNG, KECAMATAN PATUK, GUNUNGKIDUL, DAERAH ISTIMEWA YOGYAKARTA”, Jurnal Bumi Indonesia, 2(1).

[137] ANDRIA AGUSTA, YULIASRI JAMAL, MINDARTI HARAPINI . 1997 . "Components of Essential Oil From Kayu Manis Halmahera", HAYATI Journal of Biosciences, 4(1).

[138] Lukmandaru, Ganis . 2011 . "Komponen Kimia Kayu Jati dengan Pertumbuhan Eksentris", Jurnal Ilmu Kehutanan, 5(1).

[139] Purwanto, Ris Hadi , Kurniasari, Dian Asih . 2009 . "Potensi Kayu Perkakas dan Kayu Bakar Jenis Jati (Tectona grandis) di Hutan Rakyat Desa Natah, Gunung Kidul”, Jurnal Ilmu Kehutanan, 3(2). 
[140] Anggoro, Didi Dwi, Budi, Faleh Setia . 2008 . "PROSES GLISEROLISIS MINYAK KELAPA SAWIT MENJADI MONO DAN DIACYL GLISEROL DENGAN PELARUT N-BUTANOL DAN KATALIS MgO”, REAKTOR, 12(1).

[141] Irawan, RM Bagus . 2010 . "EFEKTIFITAS KATALIS MATERIAL SUBSTRAT PADUAN CuZn (KUNINGAN) DALAM MEREDUKSI EMISI GAS KARBON MONOKSIDA MOTOR BENSIN", mechanical engineering, 10(2).

[142] Irawan, RM. Bagus . 2006 . "PENGARUH KATALIS TEMBAGA DAN KROM TERHADAP EMISI GAS CARBON MONOKSIDA DAN HIDRO CARBON PADA KENDARAAN MOTOR BENSIN", mechanical engineering, 4(1).

[143] Mukaromah, Ana Hidayah . 2005 . "EFEKTIVITAS FOTODEGRADASI P-KLOROFENOL DENGAN KATALIS TIO2", JURNAL LITBANG, 2(2).

[144] Agus Wibowo, Agus Wibowo . 2010 . "LAJU REAKSI PENCAMPURAN MINYAK JARAK DAN AIR PADA HYDROGEN REFORMER MENGGUNAKAN PEMANAS DAN KATALIS", Prosiding Seminar Nasional Sains Dan Teknologi Fakultas Teknik, 1(1).

[145] Widihati, Ida Ayu Gede, Diantariani, Ni Putu, Nikmah, Yuliana Farhatun . 2011 . "FOTODEGRADASI METILEN BIRU DENGAN SINAR UV DAN KATALIS A12O3", Journal of Chemistry, 5(1).

[146] Suirta, I Wayan, Rustini, Ni Luh, Iqbal Prakasa, Taka . 2012 . "SINTESIS POLIEUGENOL DARI EUGENOL DENGAN KATALIS ASAM NITRAT PEKAT DAN MEDIA NATRIUM KLORIDA”, Journal of Chemistry, 6(1).

[147] Aritonang, Henry F., Tangkuman, Herling D. . 2009 . "REAKSI ESTERIFIKASI GARAM ASAM LEMAK DENGAN ALKIL KLORIDA BERANTAI PANJANG MENGGUNAKAN TRIDODEKILAMIN HIDROKLORIDA SEBAGAI KATALIS PERPINDAHAN DUA FASA”, CHEMISTRY PROGRESS, 2(1). 
[148] Lesbani, Aldes, Mohadi, Risfidian . 2012 . “TRIPEL ARILASI ORGANOSILIKA PRIMER DENGAN BEBERAPA ARIL IODIDA MENGGUNAKAN KATALIS PALADIUM", CHEMISTRY PROGRESS, 5(2).

[149] Ekowati, Juni . 2010 . "Pengaruh Katalis pada Sintesis Asam OMetoksisinamat dengan Material Awal O-Metoksi Benzaldehida dan Uji Aktivitas Analgesiknya", Majalah Farmasi Airlangga, 8(2).

[150] Purwanto, Ris Hadi , Kurniasari, Dian Asih . 2009 . "Potensi Kayu Perkakas dan Kayu Bakar Jenis Jati (Tectona grandis) di Hutan Rakyat Desa Natah, Gunung Kidul”, Jurnal Ilmu Kehutanan, 3(2). 